KHAZANAH MULTIDISIPLIN

VOL 2 NO 12021

https://journal.uinsgd.ac.id/index.php/kl

\title{
METABOLISME LIPID PADA DAGING BABI DAN KEMUDHARATANNYA BERDASARKAN PENJELASAN AL- QURAN DAN SAINS
}

\author{
Assyifa Junitasari \\ Kimia, Fakultas Sains dan Teknologi, UIN Sunan Gunung Djati Bandung \\ Email : assyifajunitasari@uinsgd.ac.id
}

\begin{abstract}
Metabolism plays a role in changing food substances such as glucose, amino acids, and fatty acids into compounds needed for life processes such as energy sources (ATP). Metabolic processes that occur in all body tissues which occur under the same conditions or reaction conditions require physicochemical and chemical requirements that are not much different from each other. Fat is considered by many to be a component of a diet that must be reduced as much as possible. However, this is not beneficial for health because of a certain amount of fat, usually about $30 \%$ of the total energy needed to carry out its functions properly in the body. Sources of fat usually there are many from animal sources, one of which contains a lot of pork fat content in it. However, according to Islamic teachings and written in Al-Quran that pork should not be consumed because it is included in illicit food. This paper aims to find out the understanding of fat metabolism, to find out the fat content in the body of pigs, and to know the unlawfulness of pork in Al-Quran. The writing method used is the method of literature, the author gets information through various references from the internet, as well as Al-Quran and commentary books. This paper was made as a reference or guide for readers and also lecturers and students of UIN Sunan Gunung Djati Bandung, especially the chemistry department of the Faculty of Science and Technology in the learning process as a manifestation of Revelation Guiding Science (WMI). In addition, we can practice in life.
\end{abstract}

Keywords: Al-Qur'an and science, lipid metabolism, science

\begin{abstract}
ABSTRAK
Metabolisme berperan mengubah zat-zat makanan seperti glukosa, asam amino, dan asam lemak menjadi senyawa-senyawa yang diperlukan untuk proses kehidupan seperti sumber energi (ATP). Proses metabolisme yang terjadi didalam seluruh jaringan tubuh dimana terjadi pada kondisi yang sama atau kondisi reaksinya memerlukan persyaratan fisikokimia serta kimia yang tidak banyak berbeda satu dengan yang lain. Lemak dianggap oleh banyak orang sebagai komponen diet yang harus dikurangi sebanyak mungkin. Akan tetapi, hal ini tidak menguntungkan bagi kesehatan karena lemak dalam jumlah tertentu, biasanya sekitar 30\% dari energi total diperlukan untuk menjalankan fungsinya dalam tubuh dengan baik. Sumber lemak biasanya terdapat banyak dari sumber hewani, daging babi salah satunya mengandung banyak sekali kandungan lemak didalamnya. Akan tetapi menurut ajaran islam dan tertulis didalam Al-Quran bahwa daging babi tidak boleh dikonsumsi karena termasuk kedalam makanan haram. Makalah ini bertujuan untuk mengetahui pengertian metabolisme lemak, mengetahui kandungan lemak yang ada dalam tubuh babi, dan mengetahui kemudharatan haramnya daging babi dalam Al-Quran. Metode penulisan yang digunakan adalah metode kepustakaan, yaitu penulis mendapatkan informasi melalui berbagai referensi dari internet, maupun $\mathrm{Al}$ Quran dan buku tafsiran. Makalah ini dibuat adalah sebagai acuan atau panduan untuk para pembaca dan juga Dosen maupun mahasiswa UIN Sunan Gunung Djati Bandung khusunya jurusan kimia Fakultas Sains dan Teknologi dalam proses pembelajaran
\end{abstract}


KHAZANAH MULTIDISIPLIN

VOL 2 NO 12021

https://journal.uinsgd.ac.id/index.php/kl

sebagai wujud dari Wahyu Memandu Ilmu (WMI). Selain itu juga, kita dapat mengamalkan dalam kehidupan.

Kata Kunci: Al-Qur'an dan sains, metabolisme lipid, sains

\section{PENDAHULUAN}

Umat islam dilarang memakan daging babi, dalam surat AlBaqoroh ayat 173 disebutkan :

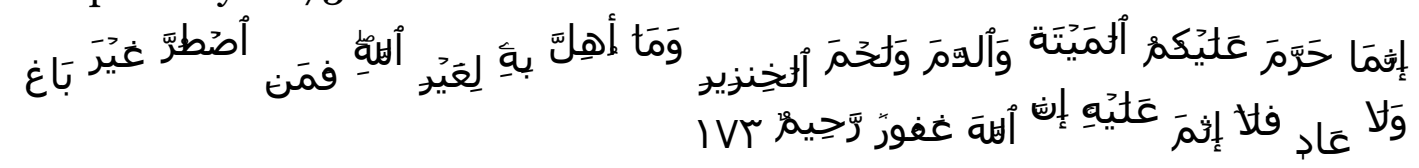

"Sesungguhnya Allah hanya mengharamkan bagimu bangkai, darah, daging babi, dan binatang yang (ketika disembelih) disebut (nama) selain Allah. Tetapi barang siapa dalam keadaan terpaksa (memakannya) sedang dia tidak menginginkannya dan tidak (pula) melampaui batas, maka tidak ada dosa baginya. Sesungguhnya Allah Maha Pengampun lagi Maha Penyayang."

Namun ternyata haramnya hewan ini tak hanya dijelaskan dalam ajaran agama Islam. Secara sains, babi memiliki kandungan tubuh yang berbeda dengan binatang lainnya.

Mengutip dari berbagai sumber, daging babi dianggap sebagai salah satu jenis daging yang mengandung kolestrol paling banyak dan akan menyebabkan penyumbatan pembuluh darah. Selain itu, jumlah asam lemak dalam daging ini tidak biasa jika dibandingkan dengan jenis makanan lain, sehingga dapat meningkatkan kadar kolesterol.

Kandungan lain yang berbahaya yaitu daging babi mengandung cacing pita yang bisa tumbuh dengan panjang 2-3 meter. Pertumbuhan telur cacing pita dalam tubuh manusia dapat menyebabkan gila dan histeris jika cacing berada di sekitar otak.

Cacing lain yang tumbuh dalam tubuh babi yaitu trichinosis yang tak dapat dibunuh meskipun dimasak. Tumbuhnya cacing ini dalam tubuh manusia dapat menyebabkan kelumpuhan dan ruam kulit.

Tak hanya cacing, babi juga membawa bibit penyakit seperti bakteri tuberkulosis (TBC) dan bakteri lain, virus cacar, serta parasit protozoa. 
KHAZANAH MULTIDISIPLIN

VOL 2 NO 12021

https://journal.uinsgd.ac.id/index.php/kl

Hubungan antara ilmu kimia dan Ilmu Al-Quran saling berkaitan. Hal tersebut dapat dilihat, misalnya dari proses pencernaan makanan dalam tubuh yang tidak lepas dari kedua ilmu tersebut. Lipid yang terdapat dalam makanan sebagaian besar berupa lemak, oleh karena itu yang dibahas paling utama dalam makalah ini adalah metabolisme lipid.

Metabolisme berperan mengubah zat-zat makanan seperti glukosa, asam amino, dan asam lemak menjadi senyawa-senyawa yang diperlukan untuk proses kehidupan seperti sumber energi (ATP).Proses metabolisme yang terjadi didalam seluruh jaringan tubuh dimana terjadi pada kondisi yang sama atau kondisi reaksinya memerlukan persyaratan fisikokimia se rta kimia yang tidak banyak berbeda satu dengan yang lain. (Suarsana, 2012).

Lemak dianggap oleh banyak orang sebagai komponen diet yang harus dikurangi sebanyak mungkin. Akan tetapi, hal ini tidak menguntungkan bagi kesehatan karena lemak dalam jumlah tertentu, biasanya sekitar 30\% dari energi total diperlukan untuk menjalankan fungsinya dalam tubuh dengan baik. Seperti terdapat pada Al-Quran surat Al-An'am ayat 145 :

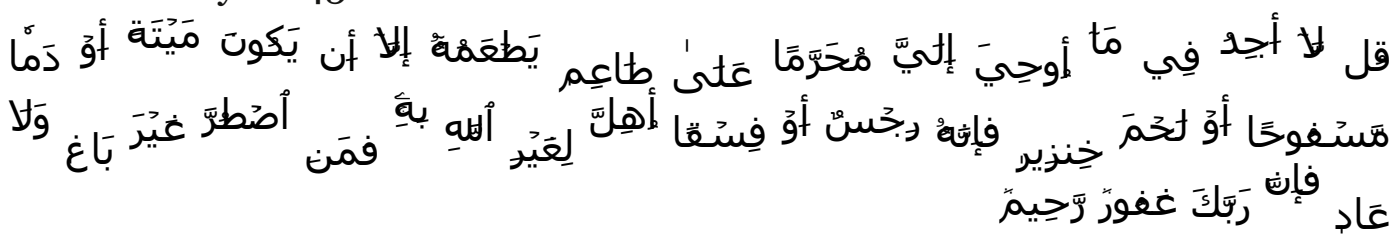

Katakanlah: "Tiadalah aku peroleh dalam wahyu yang diwahyukan kepadaku, sesuatu yang diharamkan bagi orang yang hendak memakannya, kecuali kalau makanan itu bangkai, atau darah yang mengalir atau daging babi -- karena sesungguhnya semua itu kotor -atau binatang yang disembelih atas nama selain Allah. Barangsiapa yang dalam keadaan terpaksa, sedang dia tidak menginginkannya dan tidak (pula) melampaui batas, maka sesungguhnya Tuhanmu Maha Pengampun lagi Maha Penyayang". 
KHAZANAH MULTIDISIPLIN

VOL 2 NO 12021

https://journal.uinsgd.ac.id/index.php/kl

\section{METODE PENULISAN}

Metode penulisan yang digunakan adalah metode kepustakaan, yaitu penulis mendapatkan informasi melalui berbagai referensi dari internet, maupun Al-Quran dan buku tafsiran.

\section{HASIL DAN PEMBAHASAN}

\section{Pengertian Metabolisme Lipid}

Salah satu proses kimiawi yang terjadi didalam tubuh adalah proses metabolisme. Dalam bahasan yunani kata metabolisme memiliki arti berubah. Dalam prosesnya metabolisme sangat banyak memerlukan energi karena dalam proses metabolisme akan terjadi berbagai macam reaksi kimia.

Metabolisme adalah semua reaksi kimia yang terjadi di dalam organisme, termasuk yang terjadi di tingkat seluler. Secara umum, metabolisme memiliki dua arah lintasan reaksi kimia organik, yaitu :

$\checkmark$ Katabolisme adalah reaksi yang mengurai molekul senyawa organik untuk mendapatkan energi

$\checkmark$ Anabolisme adalah reaksi yang merangkai senyawa organnik dari molekul-molekul tertentu, untuk diserap oleh sel tubuh

Metabolisme lipid berarti proses pembentukan atau penguraian lipid yang terjadi di dalam organisme, termasuk terjadi di tingkat sel yang melibatkan peran enzim.

Protein, karbohidrat dan lemak merupakan contoh sumber energi yang digunakan dalam proses metabolisme. Bahkan ada beberapa hewan yang menggunakan lemak sebagai cadangan ketika sumber energy utama sudah habis. yang mana energy tersebut bisa digunakan sewaktu waktu.

Metabolisme lipid atau lemak adalah sebuah proses dimana asam lemak yang masuk kedalam tubuh dicerna dan kemudian dipecah sebagai energi dan nantinya disimpan dalam tubuh manusia untuk penggunaan energy dimasa yang akan datang. 
KHAZANAH MULTIDISIPLIN

VOL 2 NO 12021

https://journal.uinsgd.ac.id/index.php/kl

Karena memiliki rantai karbon yang lebih panjang lemak dijadikan sebagai Sumber energy seluler terbaik untuk proses metabolisme, sehingga energy yang disimpan jauh lebih besar.

Sebelum dipakai sel menghidrolisis, lemak masih dalam bentuk asam lemak dan gliserol, lalu gliserol akan diubah menjadi 3 fosfogliseraldehid dan memasuki jalur glikolisis.

Asam lemak dipecah menjadi dua rantai karbon yang masuk ke siklus krebs sebagai asetil koA. Melalui jalur-jalur tersebut, satu gram lemak memberikan ATP menjadi lebih banyak dari pada protein dan karbohidrat. Satu gram lemak mampu menghasilkan 9 kkal energi.

Lipid adalah sekelompok senyawa organik yang cenderung tidak larut dalam air dan pelarut polar lainnya, tetapi dapat larut dalam pelarut organik seperti toluena atau eter. Lipid terutama terdiri atas unsur karbon, hidrogen, dan oksigen, namun bisa juga mengandung unsur-unsur lain (Fried, 2006).

Secara umun, lipid merupakan konduktor panas yang bisa dibilang jelek, sehingga lipid dalam tubuh makhluk hidup memiliki fungsi untuk mencegah terjadinya kehilangan panas tubuh. Tak hanya itu lemak juga memiliki fungsi didalam melindungi organ-organ tubuh tertentu dari kerusakan yang diakibatkan benturan atau goncangan. Fungsi yang paling utama dari metabolisme lipid adalah sebagai sumber energi dan sebagai senyawa yang melarutkan vitamin A,D,E dan $\mathrm{K}$.

\section{Kandungan Lemak Dalam Tubuh Babi}

Babi adalah hewan yang sangat kotor karena biasanya memakan segala sesuatu yang diberikan kepadanya dari mulai bangkai, kotorannya sendri sampai kotoran manusia. Secara psikis babi memiliki tabiat yang malas, tidak menyukai matahari, sangat suka makan dan tidur, memiliki sifat tamak, dan tidak memiliki kehendak dan daya juang, bahkan untuk mebela diri sekalipun. 
KHAZANAH MULTIDISIPLIN

VOL 2 NO 12021

https://journal.uinsgd.ac.id/index.php/kl

Tabel Presentase Kandungan Lemak Beberapa Jenis Daging

\begin{tabular}{llll}
\hline Jenis Daging & \multicolumn{4}{l}{ Presentase Kandungan Lemak (\%) } \\
\cline { 2 - 4 } & Gemuk & Sedang & Kurus \\
Daging Sapi & 35 & 20 & 6 \\
Daging Babi & 91 & 60 & 29 \\
Daging Kambing & 56 & 29 & 14 \\
\hline
\end{tabular}

(Republika.com)

Disamping itu daging babi adalah daging yang paling sulit dicerna, karena kandungan zat lemaknya sangat tinggi. Selain itu jika dibiarkan berada di udara terbuka maka daging yang pertama kali busuk adalah daging babi, diikuti daging kambing dan yang terakhir daging sapi. Akan tetapi apabila daging-daging tersebut dimasak, maka yang paling lambat masaknya adalah daging babi. Memakan daging babi yang terjangkit cacing babi tidak hanya berbahaya, tetapi juga dapat menyebabkan meningkatnya kandungan kolesterol dan memperlambat proses penguraian protein dalam tubuh. Meskipun empuk dan terlihat begitu enak dan lezat, namun daging babi sulit dicerna. Ibaratnya racun, seperti halnya kolesterol.

\section{Kemudharatan dan Keharaman Daging Babi dalam Al-Quran}

Alloh SWT telah menjelaskan bahwa diharamkannya daging babi terdapat dalam Al-Quran :

Surat Al-An'am ayat 145

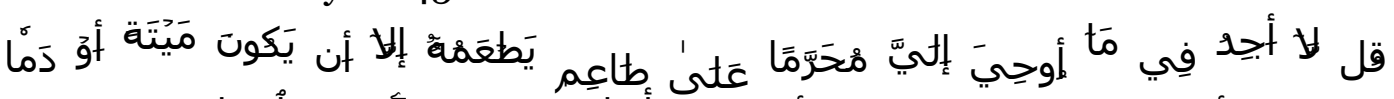

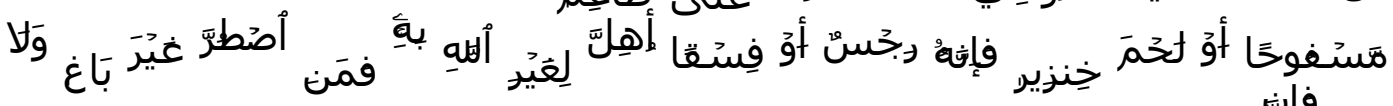

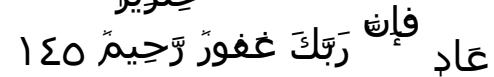

Katakanlah: "Tiadalah aku peroleh dalam wahyu yang diwahyukan kepadaku, sesuatu yang diharamkan bagi orang yang hendak memakannya, kecuali kalau makanan itu bangkai, atau darah yang mengalir atau daging babi -- karena sesungguhnya semua itu kotor -- 
KHAZANAH MULTIDISIPLIN

VOL 2 NO 12021

https://journal.uinsgd.ac.id/index.php/kl

atau binatang yang disembelih atas nama selain Allah. Barangsiapa yang dalam keadaan terpaksa, sedang dia tidak menginginkannya dan tidak (pula) melampaui batas, maka sesungguhnya Tuhanmu Maha Pengampun lagi Maha Penyayang".

Surat Al-Baqoroh ayat 173

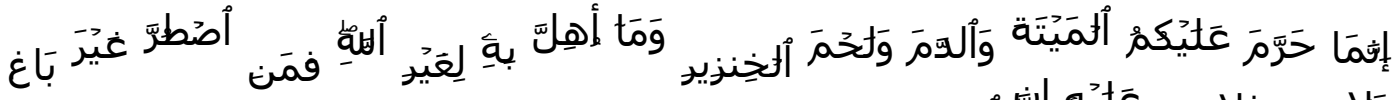

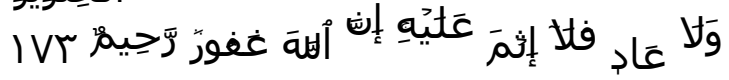

"Sesungguhnya Allah hanya mengharamkan bagimu bangkai, darah, daging babi, dan binatang yang (ketika disembelih) disebut (nama) selain Allah[108]. tetapi Barangsiapa dalam Keadaan terpaksa (memakannya) sedang Dia tidak menginginkannya dan tidak (pula) melampaui batas, Maka tidak ada dosa baginya. Sesungguhnya Allah Maha Pengampun lagi Maha Penyayang."

Haram juga menurut ayat ini daging yang berasal dari sembelihan yang menyebut nama Alloh tetapi disebut pula nama selain Alloh, karena sebagai muslim apabila kita ingin menyembelih binatang harus menyebut nama Alloh SWT yang terdapat dalam Al-Quran, yaitu surat Al-Maidah ayat 5 .

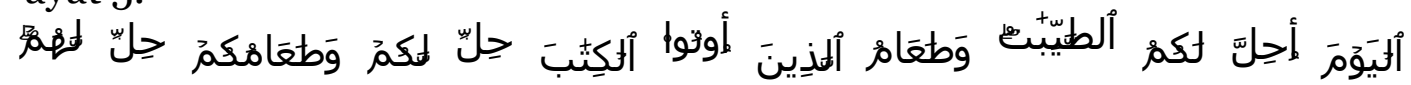

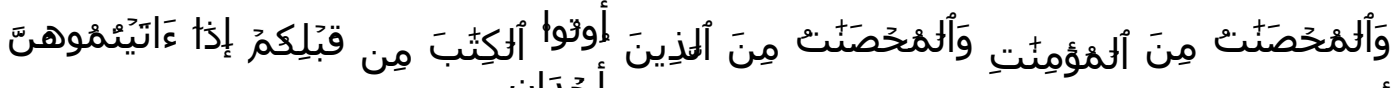
فقد حَبط

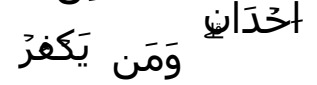

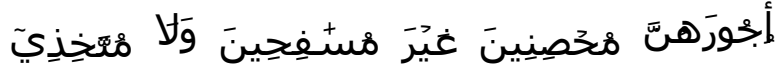

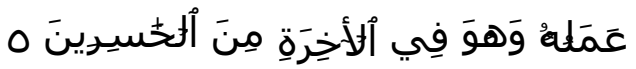
"Diharamkan bagimu (memakan) bangkai, darah, daging babi, (daging hewan) yang disembelih atas nama selain Allah, yang tercekik, yang terpukul, yang jatuh, yang ditanduk, dan diterkam binatang buas, kecuali yang sempat kamu menyembelihnya, dan (diharamkan bagimu) yang disembelih untuk berhala. dan (diharamkan juga) mengundi nasib dengan anak panah, (mengundi nasib dengan anak panah itu) adalah kefasikan. pada hari ini orang-orang kafir telah putus asa untuk (mengalahkan) agamamu, sebab itu janganlah kamu takut kepada mereka dan takutlah kepada-Ku. pada hari ini telah Kusempurnakan 
KHAZANAH MULTIDISIPLIN

VOL 2 NO 12021

https://journal.uinsgd.ac.id/index.php/kl

untuk kamu agamamu, dan telah Ku-cukupkan kepadamu nikmat-Ku, dan telah Ku-ridhai Islam itu Jadi agama bagimu. Maka barang siapa terpaksa karena kelaparan tanpa sengaja berbuat dosa, Sesungguhnya Allah Maha Pengampun lagi Maha Penyayang”

Maksud dari ayat tersebut apabila muslim terpaksa memakan karena kelaparan, maka dibolehkan memakan makanan yang diharamkan oleh ayat ini jika terpaksa. Ayat tersebut terkandung dalam surat An-Nahl ayat 115 .

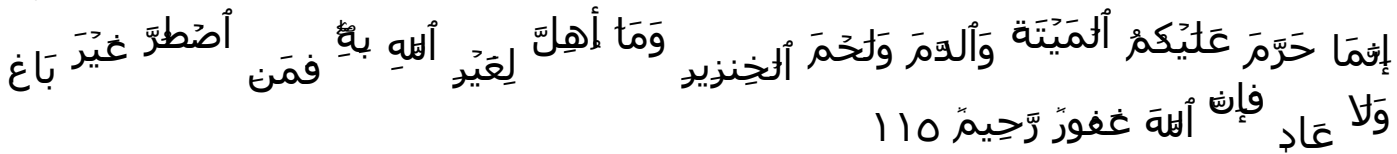

"Sesungguhnya Allah hanya mengharamkan atasmu (memakan) bangkai, darah, daging babi dan apa yang disembelih dengan menyebut nama selain Allah; tetapi Barangsiapa yang terpaksa memakannya dengan tidak Menganiaya dan tidak pula melampaui batas, Maka Sesungguhnya Allah Maha Pengampun lagi Maha Penyayang”.

Banyaknya temuan-temuan scientific (ilmiah), medis, maupun realita di lapangan mengenai besarnya mudharat daging babi. Terkait kemudharatan daging babi, ada beberapa alasan yang menjelaskan hal tersebut:

a) Babi adalah binatang yang paling jorok dan kotor.

b) Babi suka memakan bangkai dan kotorannya sendiri. Kotoran manusia pun dimakannya. Babi juga sangat suka berada pada tempat yang kotor, tidak suka berada di tempat yang bersih dan kering.

c) Babi banyak punya tabiat yang tidak baik.

d) Menurut A.V. Nalbandov dan N.V. Nalbandov, 1990, konsumen daging babi sering mengeluhkan bau pesing pada daging babi. Menurut penelitian ilmiah, hal tersebut disebabkan karena praeputium (kantong penis) babi sering bocor, sehingga urin babi tersebut merembes ke daging. 
KHAZANAH MULTIDISIPLIN

VOL 2 NO 12021

https://journal.uinsgd.ac.id/index.php/kl

e) Babi memiliki back fat (lemak punggung) yang lumayan tebal.)karena mempunyai kandungan lemak yang sangat tinggi sehingga sudah tidak layak dikonsumsi.

f) Kulit orang yang memakan babi akan mengeluarkan bau yang tidak sedap.

g) Babi dikatakan sebagai reservoir (tempat menyimpan barang cadangan) penyakit. Hal ini disebabkan babi banyak mengandung parasit, bakteri, bahkan virus yang berbahaya, antara lain: Virus Encephalitis (menyerang otak kecil).

h) Daging babi adalah tempat persinggahan bagi beberapa jenis cacing yang berbahaya. Diantara cacing yang terdapat pada babi antara lain: Cacing pita (Taenia solium), Cacing spiral (Trichinella spinalis), Cacing tambang (Ancylostoma duodenale), Cacing paruparu (Paragonimus). Cacing-cacing tersebut akan menyedot sarisari makanan. Akibatnya dapat terjadi anemia (kurang darah), gangguan pencernaan, diare, histeria, mudah kaget, dan lain-lain.

i) Terdapat bermacam-macam bakteri dan virus yang terdapat pada babi, antara lain: Bakteri Tuberculosis (TBC), Virus cacar (Small pox), penyebab kudis (Scabies), Kolera (Salmonella choleraesuis).

j) Penyakit lain yang ditularkan adalah Kolera Babi, yaitu penyakit berbahaya yang disebabkan oleh virus dan dapat menyebabkan kematian..

k) Dr. Murad Hoffman, seorang Muslim Jerman penulis buku Pergolakan Pemikiran: Catatan Harian Muslim Jerman menyatakan dalam bukunya bahwa memakan daging babi yang terjangkiti cacing babi tidak hanya berbahaya, tetapi juga dapat menyebabkan meningkatnya kandungan kolestrol dan memperlambat proses penguraian protein dalam tubuh.

1) Prof Dr. Abdul Basith Muhammad Sayyid, penulis buku Rahasia Kesehatan Nabi,mengungkapkan dalam bukunya bahwa daging babi adalah daging yang sangat sulit dicerna karena banyak 
KHAZANAH MULTIDISIPLIN

VOL 2 NO 12021

https://journal.uinsgd.ac.id/index.php/kl

mengandung lemak. Meskipun empuk dan terlihat begitu enak dan lezat, namun daging babi sulit dicerna. Ibaratnya racun, seperti halnya kolesterol.

\section{SIMPULAN}

Metabolisme Lipid ialah proses pembentukan atau penguraian lipid yang terjadi di dalam organisme, termasuk terjadi di tingkat sel yang melibatkan peran enzim. Babi adalah hewan yang sangat kotor karena biasanya memakan segala sesuatu yang diberikan kepadanya dari mulai bangkai, kotorannya sendiri sampai kotoran manusia. Memakan daging babi yang terjangkiti cacing babi tidak hanya berbahaya, tetapi juga dapat menyebabkan meningkatnya kandungan kolestrol dan memperlambat proses penguraian protein dalam tubuh. Berdasarkan dari berbagai sumber, maka daging babi memiliki kandungan lemak Babi gemuk 91\%,Babi sedang 60\%, dan Babi kurus 29\%. Kemudhartan daging babi di karenakan daging babi sudah di haramkan bagi orang muslim, bau, suka memakan bangkai, kotor, dan babi sebagai tempat persinggahan cacingcacing.

Saya mengharapkan setelah memahami penelitian ini, maka sebagai dosen maupun mahasiswa dapat lebih mudah memahami serta mengkaji materi pembelajaran selanjutnya. Serta menyadari betapa Maha Kuasa Allah yang telah mengatur semua ini sedemikian kompleks. Sebagai Muslim/muslimah kita harus menjalankan syariat-syariat Islam dan menjauhi larangan- larangan Allah SWT. Agar menjadi makhluk yang patuh terhadap Sang Pencipta. Sebagai Muslim/Muslimah kita dapat menjadikan pelajaran tentang sesuatu hal yang dapat memberikan kemudharatan bagi hidup serta kita dapat mengkaji dalam menjalankan ibadah.

\section{DAFTAR PUSTAKA}

Fried, George H., Hademenos, George J. (2006) . Schaum's Outlines Biology 2nd. Jakarta: Erlangga 
KHAZANAH MULTIDISIPLIN

VOL 2 NO 12021

https://journal.uinsgd.ac.id/index.php/kl

Mary E Barasi.2009. At a Glance Ilmu Gizi Jakarta : Erlangga

Nuramaya. 2008. Di Balik Alasan di Haramkannya Bangkai, Darah, Daging Babi dan Khamr

Poedjiadi, Anna. F.M. Titin Supriyanti. (2006). Dasar-dasar Biokimia. Jakarta: UI Press

Rusdiana. (2004). Metabolisme Asam Lemak. Universitas Sumatera Utara. Sumatera Utara.

Suarsana, N. (2012). Regulasi Metabolisme dan Sistem Organ. Fakultas Kedoteran Universitas Udayana. Bali. 